\title{
ANALISIS PENGARUH PERENCANAAN PAJAK TERHADAP NILAI PERUSAHAAN PADA PERUSAHAAN SEKTOR PERTANIAN YANG TERDAFTAR DI BURSA EFEK INDONESIA
}

\author{
Yuningsih Nita Christiani ${ }^{1}$,Melvin K Djami Rane ${ }^{2}$, Devit Alfan Sine ${ }^{3}$ \\ Fakultas Ekonomi Universitas Kristen Artha Wacana ${ }^{1,2,3}$ \\ 1) yuningsih.fe@ukaw.ac.id \\ 2) melvinkristen@gmail.com \\ 3) davitsine13@gmail.com
}

\begin{abstract}
ABSTRAK
Penelitian yang lakukan oleh peneliti adalah untuk dapat melihat serta menganalisa pengaruh perencanaan pajak terhadap nilai perusahaan bidang pertanian yang terdaftar di Bursa Efek Indonesia. Penelitian ini mengukur perencaan pajak diukur dengan Effective Tax Rate (ETR) sebagai variabel independen dan mengukur nilai perusahaan dengan Price Earning to Ratio (PER) sebagai variabel dependen. Sampel penelitian berjumlah 15 perusahaan pertanian yang terdaftar Bursa Efek Indonesia periode tahun 2015-2019. Dalam menganalisa penelitian menggunakan SPSS. 20 Hasil Temuan Penelitian Dapat disimpulkan bahwa Pengujian yang telah dilakukan ini menunjukkan bahwa $\mathrm{H} 1$ diterima dan $\mathrm{HO}$ ditolak artinya perencanaan pajak berpengaruh positif dan signifikan terhadap nilai perusahaan nilai t-hitung 2,022 sedangkan t-tabel 1,993, t-hitung > dari t-tabel dengan berpengaruh positif dan signifikan terhadap nilai perusahaan.
\end{abstract}

Kata kunci: Perencanaan Pajak, Nilai Perusahaan.

\section{PENDAHULUAN}

Tujuan perusahaan untuk menaikan nilai dari setiap perusahaan pada setiap periode adalah direflesikan atas dasar harga pasar saham perusahaan. Jika Nilai perusahaan bisa terus meningkat maka setiap investor atau pemegang saham perusahaan juga akan meningkat, yang terlihat dari return saham bagi investor. Hal di atas dapat menjadi stimulus atau motivasi bagi investor untuk menanamkan modalnya di perusahaan. Sehingga nilai saham perusahaan di pasar akan tinggi bila nilai perusahannya juga tinggi. Salah satu indikator yang digunakan oleh para pemegang saham dalam pengambilan keputusan investasi dengan melihat keuntungan dari harga nilai buku saham atau price earning ratio. Ini dapat menunjukkan seberapa banyak investor atau para pemegang saham bersedia membayar untuk setiap laba yang dilaporkan. Makin besar PER suatu saham maka harga saham tersebut akan semakin mahal terhadap pendapatan bersih per sahamnya. PER juga merupakan rumusb dalam pengukuran untuk menunjukkan tingkat pertumbuhan perusahaan. PER yang tinggi menunjukkan prospek pertumbuhan perusahaan yang bagus.

Dampak keputusan manajemen terhadap nilai perusahaan adalah keputusan untuk melakukan Perencanaan Pajak (Tax Planning). Tax Planning dalam hal ini adalah proses mengorganisasi usaha wajib pajak orang pribadi maupun badan usaha sedemikian rupa dengan memanfaatkan berbagai celah kemungkinan yang dapat ditempuh oleh 
perusahaan dalam koridor ketentuan peraturan perpajakan, agar perusahaan dapat membayar pajak dalam jumlah minimum.

Setiap Beban pajak perusahaan yang dipikul oleh subjek pajak badan, memerlukan perencanaan pajak yang baik dan tentu saja harus legal, mampu mendorong perusahaan untuk dapat bersaing dengan perusahaan yang lain, ketika perusahaan mampu meminimalkan pengeluaran atau biaya untuk keperluan perpajakan, berarti semakin sedikit beban yang dikeluarkan oleh perusahaan untuk pemerintah jikalau semakin kecil setiap beban yang dikeluarkan perusahaan maka laba yang akan diperoleh perusahaaan semakin besar dan akan berdampak pada investor semakin tinggi saham perusahaan yang memperoleh laba besar artinya semakin tinggi minat investor akan suatu saham pada perusahaan.

Perencanaan pajak dapat diukur dengan menggunakan Tarif Pajak Efektif atau Efective Tax Rate (ETR). Tarif Pajak Efektif adalah besarnya tarif pajak yang berlaku atau yang harus diterapkan atas dasar pengenaan pajak tertentu. Dalam hal ini pajak penghasilan, dasar pengenaan pajak yang digunakan lazimmnya adalah penghasilan netto.

Setiap Tarif Pajak Efektif perusahaan dinilai menjadi indikator adanya perencanaan pajak apabila memiliki nominal yang mendekati nol. Semakin rendah Tarif Pajak Efektif yang perudahaan mililki maka semakin tinggi tingkat perencanaan pajak. Tarif Pajak Efektif yang rendah menunjukkan laba pajak penghasilan lebih kecil dari pendapatan sebelum pajak. Semakin tinggi perencanaan pajak dalam suatu perusahaan maka akan mempengaruhi laba dan pendapatan suatu perusahaan ataupun juga harga saham perusahaan, dengan demikian hal tersebut akan berdampak pada nilai perusahaan juga akan semakin meningkat.

Penelitian terdahulu oleh menyatakan bahwa (Yuliem, 2018) perencanaan tidak berpengaruh pada nilai perusahaan. Yang beraartiu berarti bahwa tinggi rendahnya nilai sebuah perusahaan tidak berpengaruh pada tinggi rendahnya perencanaan pajak yang dilakukan oleh setiap perusahaan. Penelitian lainnya juga (Hani, 2021) menyatakan bahwa perencanaan pajak berpengaruh positif terhadap nilai perusahaan, yang dimana apabila beban pajak naik maka akan diikuti oleh dengan kenaikan Tarif Pajak Efektif. Dengan meningkatknya Tarif Pajak Efektif maka diikuti dengan meningkatnya nilai laba per saham.

Dalam penelitian pada perusahaan sektor pertanian yang terdaftar di Bursa Efek Indonesia ini peneliti akan menganalisis pengaruh perencanaan pajak terhadap nilai perusahaan apakah dengan menggunakan pengukuran perencanaan pajak (Effective Tax rate) dapat meningkatkan nilai perusahaan (Price Earning Ratio)

\section{LANDASAN TEORI DAN PENGEMBANGAN HIPOTESIS}

\section{Pengertian Pajak}

(Mardiasmo, 2018) menyatakan bahwa "pajak adalah iuran rakyat kepada kas negara berdasarkan undang-undang (yang dapat dipaksakan) dengan tiada mendapat jasa timbal (kontrapertasi) yang langsung dapat ditunjukan dan digunakan untuk membayar pengeluaran umum".

Menurut Pasal 1 ayat (1) UU No 16 tahun 2009 tentang Ketentuan Umum dan Tata Cara Perpajakan "Pajak adalah kontribusi wajib kepada negara yang terutang oleh pribadi atau badan yang bersifat memaksa berdasrkan undang-undang. Dengan tidak 
mendapatkan imbalan secara langsung dan digunakan untuk keperluan Negara bagi sebesar-besarnya kemakmuran rakyat.

\section{Fungsi Pajak}

Sebagaimana telah diketahui ciri-ciri yang melekat pada pengertian pajak dari berbagi defenisi, terlihat adanya dua fungsi pajak yaitu: (1) Fungsi Penerimaan (Budgetair) Pajak berfungsi sebagai sumber dana yang diperuntukkan dalam pembiayaan pengeluaran-pengeluaran pemerintah contoh dimasukkannya pajak dalam APBN sebagai penerimaan dalam negeri. (2) Fungsi mengatur (reguler) pajak sebagai alat dalam mengatur atau melaksanakan kebijakan dibidang sosial dan ekonomi. Sebagai contoh dalam rangka menggiring penanaman modal, baik dalam negeri maupun luar negeri, diberikan berbagai macam fasilitas keinginan pajak.dalam rangka melindungi produksi dalam negeri, pemerintah menetapkan bea masuk yang tinggi untuk produk luar negeri.

\section{Perencanaan Pajak}

Perencanaan Pajak adalah sebuag proses proses mengorganisasi usaha wajib pajak atau kelompok wajib pajak sedemikian rupa sehingga utang pajaknya, baik pajak penghasilan maupun pajak-pajak lainnya, berada dalam posisi paling minimum, sepanjang hal itu dimungkinkan baik oleh ketentuan peraturan perundang- undangan perpajakn maupun komersial. Selain itu, perencanaan pajak merupakan langkah awal dalam manajemen pajak . dalam setiap tahapan dilakukan pengumpulan dan penelitian terhadap peraturan perpajakan agar dapat diseleksi jenis tindakan pengehematan pajak yang dilakukan (Suandy, 2016). Beban pajak yang dipikul oleh subjek pajak badan atau perusahaan, memerlukan perencanaan yang baik, oleh karena itu strategi perpajakan menjadi multlak diperlukan untuk mencapai perusahaan yang optimal. Strategi dan perencanaan pajak yang baik dan tentu saja harus legal, akan mampu mendorong perusahaan untuk dapat bersaing dengan perusahaan yang lain.

Motivasi Perencanaan Pajak Secara umum motivasi dilakukannya perencanaan pajak (tax planning) adalah untuk memaksimalkan laba setelah pajak (after tax return), dengan memanfaatkan peluang atau kesempatan disetiap ketentuan peraturan yang dibuat oleh pemerintah untuk memberikan perlakuan yang berbeda atas objek yang secara ekonomi hakikatnya sama, atau dengan kata lain memanfaatkan perbedaan tarif pajak (tax rated) dan perbedaan perlakuan atas objek pajak sebagai dasar pengenaan pajak (tax based) (Suandy, 2016)

\section{Tujuan dan Manfaat Perencanaan Pajak}

Merekayasa agar beban pajak (tax burden) dapat ditekan serendah mungkin dengan memanfaatkan peraturan yang ada untuk memaksimalkan penghasilan setelah pajak (after tax return), karena pajak merupakan unsur pengurang laba yang tersedia, baik untuk dibagikan bagi pemegang saham yang diinvestasikan kembali. (Suandy, 2016) mengemukakan bahwa secara umum tujuan pokok dari perencanaan pajak adalah sebagai berikut :1) Meminimalisasi beban pajak yang terutang. 2) Memaksimalkan laba setelah pajak. 3)Meminimalkan terjadinya kejutan pajak (tax surprise) jika terjadi pemeriksaan pajak oleh fiskus. 4) Memenuhi kewajiban perpajakannya secara benar, efisien dan efektif, sesuai dengan ketentuan perpajakan. 5) Manfaat Perencanaan Pajak.

(Suandy, 2016) mengemukakan bahwa ada beberapa manfaat yang bisa diperoleh dari perencanaan pajak yang dilakukan secara cermat yaitu:1) Penghematan kas keluar, 
karena beban pajak yang merupakan unsur biaya dapat dikurangi. 2) Mengatur aliran kas masuk dan keluar (cash flow), karena dengan perencanaan pajak yang matang dapat diperkirakan kebutuhan kas untuk pajak.

\section{Strategi Perencanaan Pajak}

1) Jurus tax planner

Ada empat modus yang digunakan wajib pajak dalam menyusunperencanaan pembayaran pajaknya antara lain 1)Dimungkinkan untuk tidak membayar pajak sama sekali. 2) dimungkinkan untuk tidka bisa membayar pajaknya dengan tidak melanggar undang-undang perpajakan. 3) Mengeser waktu pembayaran. 4)Kalau ketiga-tiganya tidak ketemu, baru membayarpajak

2) Konsep Tax Planning

Secara umum konsepsi tentang perencanaan pajak diberikanpaling kurang pada tujuh situasi antara lain:Pada saat mempertimbangkan bentuk usaha sebelum usaha dimulai, Mempertimbangkan kembali strukur usaha dan Apabila terjadi perubahan kepemilikan perusahaan, Apabila perusahaan mempertimbangkan perolehan atas aset dalam rangka meminimalkan beban pajak, Apabila suatu perusahaan akan memperoleh PKP yang cukup besar dalam satu tahun, maka perusahaan akan mencari jalan untuk mengurangi beban pajak Apabila terjadi perubahan keadaan individu wajib pajak(pension, perkawinan, perceraian dan bila perusahaan/orang pribadi akan menjual aktivaatau perusahaan akan bubar atau orang meninggal dunia

3) Tax Planning yang Masih Berlaku

Ada beberapa trik yang perlu dipertimbangkan dalam membuatperencanaan pajak perusahaan antara lain: 1)Memaksimalkan biaya-biaya yang dapat dikurangkan.

2)Merger antara perusahaan yang terus menerus rugidengan perusahaan yang untung Menunda penghasilan. 3)Percepat pembebanan biaya Strategi efisiensi untuk menekan beban pajakperusahaan. 5) Hindari beban orang lain untuk tidak menjadi beban sendiri

Tahapan Pokok Perencanaan Pajak (Indriati, 2017) tahapan-tahapan yang harus ditempuh yaitu: 1) Melakukan analisis data base yang ada. 2)Membuat satu model atau lebih rencana besarnya pajak. 3)Melakukan evaluasi atau perencanaan pajak. 4)Mencari kelemahan dan memperbaiki kembali rencanapajak. 5) Memutakhirkan rencana pajak Pengukuran Perencanaan Pajak Pada penelitian ini, perencanaan pajak akan diukur menggunakan Tarif Pajak Efektif atau Effective Tax Rate (ETR). ETR digunakan sebagai salah satu alat ukur perencanaan pajak yang bersifat jangka pendek.

Menurut (Laksitasari, 2018) Tarif Pajak Efektif didasarnya adalah sebuah presentase besaran tariff pajakyang ditanggung oleh setiap perusahaan. Tarif pajak efektif dihitung atau dinilai atas dasar infromasi keuangan yang dihasilkan oleh perusahaan sehingga tarif pajak efektif merupakan perhitungan tarif pajak pada perusahaan.Tarif pajak efektif digunakan dalam merefleksikan perbedaan antara perhitungan laba akuntansi danlaba fiskal. Tarif pajak efektif sering digunakan untuk pengambilan keputusan dan digunakan oleh pihak yang berkepentingan untuk mengkaji sistem perpajakan perusahaan dikarenakan adanya pengaruh kumulatif dari berbagai macam keberadaan insentif pajakdan perubahan tarif pajak perusahaan. Menurut (PSAK) No 46 (Revisi 2010) Tarif Pajak Efektif rata-rata merupakan beban (penghasilan) pajak yang dibagi dengan laba akuntansi. Dapat dirumuskan sebagai berikut: 
"Effective Tax Rate = Beban Pajak/Laba Sebelum Pajak"

\section{Pengertian Nilai Perusahaan}

Nilai perusahaan merupakan presepsi para pemegang saham terhadap perusahaan, yang paling sering dikaitkan dengan harga saham. Harga saham yang nilainya tinggi akan membuat nilai perusahaan juga tinggi (Sutama \& Lisa, 2018). Setiap Nilai perusahaan yang tinggi akan membuat pasar percaya tidak hanya pada kinerja perusahaan saat ini namun juga pada prospek perusahaan dimasa yang akan datang.

\section{Karakteristik Nilai Perusahaan}

Nilai perusahaan dari setiap memiliki beberapa karakteristik antara lain:1) Dividen dibayarkan sepanjang perusahaan memperoleh nilai perusahaan, sehingga pendapatan yang diperoleh dari bagi hasil nilai perusahaan menjadi lebih tidak pasti. 2) Memiliki hak suara dalam rapat umum pemegang saham nilai perusahaan, pemegang nilai perusahaan dapat mempengaruhi kebijakan perusahaan sebesar penguasaan nilai perusahaannya. 3)Memiliki hak terakhir dalam hal pembagian kekayaan perusahaan bila perusahaan tersebut dilikuidasi (dibubarkan) setelah semua kewajiban perusahaan dilunasi. 4)Memiliki tanggung jawab terbatas terhadap klaim pihaklain sebesar proporsi nilai perusahaanya. Hak kepemilikan nilai perusahaan dapat diahlikan kepada pihak lain

Faktor-faktor yang Mempengaruhi Nilai Perusahaan

1) Ukuran perusahaan

Ukuran perusahaan dapat berpengaruh negatif terhadap nilai perusahaan, karena pada perusahaan-perusahaan besar, pemilik saham pada dasarnya terpisah dari manajemen, sehingga kurang berdaya mengubah manajemen. Ukuran perusahaan juga dapat berpengaruh negatif sekalipun perusahaan besar memiliki kemampuan untuk menghasilkankeuntungan lebih besar, namun modal yang digunakan juga besar, sehingga profitabilitasnya bisa jadi terlalu tinggi disbanding perusahaan dengan ukuran lebih kecil

2) Profitabilitas

Sejalan dengan likuiditas, jika terjadi peningkatan laba sehingga ROE meningkat, maka semakin baik kemampuan perusahaan dalam mengelola modal untuk menghasilkan laba, sehingga nilai perusahaan yang tercermin dalam price book value (PBV) akan meningkat

3) Likuiditas

Semakin tinggi likuiditas perusahaan (yang salah satunya tercermin dalam rasio kas atas aktiva lancar), semakin banyak dana tersedia bagi perusahaan untuk membayar dividen, membiayai operasi dan investasinya, sehingga presepsi investor pada kinerja perusahaan akan meningkat

4) Pertumbuhan Laba

Sama halnya dengan pertumbuhan laba dan sejalan dengan peningkatan likuiditas, jika terjadi peningkatan laba sehingga growth of earnining after tax meningkat, maka semakin baik kinerja perusahaan, sehingga nilai perusahaan yang tercermin dalam PBV akan meningkat

5) Inflasi

Inflasi berpengaruh negative terhadap nilai perusahaan. Kondisi inflasi akan menurunkan daya beli perusahaan, sehingga perusahaan akan terdorong untuk melakukan retensi dan lebih besar agar dapat terus membiayai aktivitasnya 
6) Pengukuran Nilai Perusahaan

Menurut (Sari \& Chabachib, 2013) bahwa perusahaan yang dikeloladengan baik pada umumnya memiliki rasio PER yang mahal. Hal ini menggambarkan nilai saham perusahaan lebih besar dari pada nilai buku perusahaan.Harga saham yang tinggi membuat nilai perusahaan juga tinggi. Nilai perusahaan yang tinggi akan membuat pasar percaya tidak hanya pada kinerja perusahaan saat ini namun juga pada prospek perusahaan dimasa depan. Secara sistematis price earning ratio (PER) dapat hitung dengan rumus, sebagai berikut (Brigham \& Houston, 2019)

"Price Earning Ratio = Harga Saham / Laba Per Saham"

\section{Pengembangan Hipotesis (Jika Ada)}

Berdasarkan teori diatas maka penulis menyajikan hipotesis sebagai berikut : H1 : Perencanaan Pajak berpengaruh terhadap nilai perusahaan

\section{MODEL PENELITIAN}

Dalam manajemen apabila perusahaan mampu meminimalkan pengeluaran untuk keperluan perpajakan, artinya semakin sedikit beban yang dikeluarkan oleh perusahaan. Ketika beban semakin kecil yang dikeluarkan perusahaan maka semakin besar laba yang diperoleh oleh perusahaan. Minat para investor akan semakin tinggi pada saham perusahaan yang memperoleh laba besar. Semakin tinggi minat investor akan suatu saham maka harga saham akan mengalami kenaikan karena jumlah saham yang beredar di masyarakat terbatas. Perencanaan pajak dalam penelitian ini diukur dengan tarif pajak efektif.Tarif pajak efektif adalah besarnya presentase tariff pajak yang berlaku atau yang harus diterapkan atas dasar pengenaan pajak tertentu. Menurut (Putri, 2018) Tarif pajak efektif sering digunakan untuk pengambilan keputusan dan digunakan oleh pihak yang berkepentingan dalam mengkaji sistem perpajakan perusahaan dikarenakan adanya pengaruh kumulatif dari berbagai macam keberadaan insentif pajak dan perubahan tarif pajak perusahaan.

Tarif Pajak Efektif yang nilainya tinggi maka akan mencerminkan pendapatan meningkat sehingga akan mempengaruhi nilai perusahaan. Perusahaan yang melakukan perencanaan pajak memiliki tarif pajak yang lebih kecil. Perencanaan pajak dilakukan untuk meningkatkan nilai perusahaan, sehingga manajemen terlihat baik dimata para pemegang saham.

Berdasarkan pemikiran diatas, maka penelitian ini menganalisis seberapa besar perencanaan pajak mempengaruhi nilai setiap perusahaan pada perusahaan pertanian yang terdaftar di Bursa Efek Indonesia (BEI). Sehingga terbentuklah pemikiran teoritis dalam penelitian ini sebagai berikut:

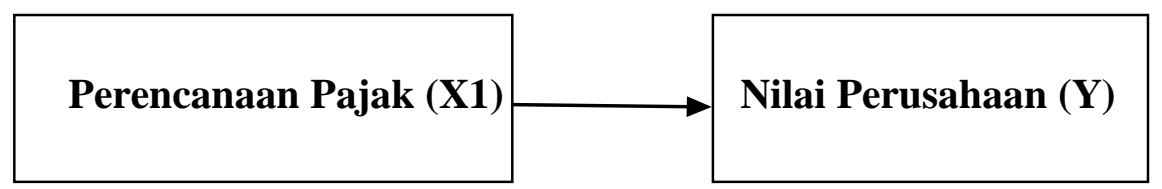

Gambar 1. Model Penelitian

\section{METODE PENELITIAN}

\section{Populasi}


Populasi adalah wilayah generalisasi yang terdiri atas: obyek/subjek yang mempunyai kualitas dan karakteristik tertentu yang diterapkan oleh peneliti untuk dipelajari dan kemudian ditarik kesimpulannya (Sugiyono, 2019). Populasi dalam penelitian ini adalah sebanyak 15 perusahaan pertanian pada tahun 2015-2019

\section{Sampel}

Sampel adalah bagian dari jumlah dan karakteristik yang dimiiki oleh populasi tersebut (Sugiyono, 2019).Sampel yang digunakan dalam penelitian ini di ambil menggunaan purposive sampling. Metode pengambilan sampel dilakukan dengan purposive sampling, yaitu teknik penentuan sampel dengan pertimbangan tertentu.Beberapa kriteria sampel yang ditentukan oleh peneliti dalam pengambilan sampel adalah :

1. Perusahaan sektor pertanian yang terdaftar di bursa efek Indonesia

2. Perusahaan telah menerbitkan dan mempublikasikan laporan keuangan dan memiliki data yang diperlukan pada tahun 2015- 2019

3. Perusahaan yang menerbitkan laporan keuangan untuk periode yang berakhir pada 31 desember

4. Perusahaan yang laporan keuangannya telah diaudit

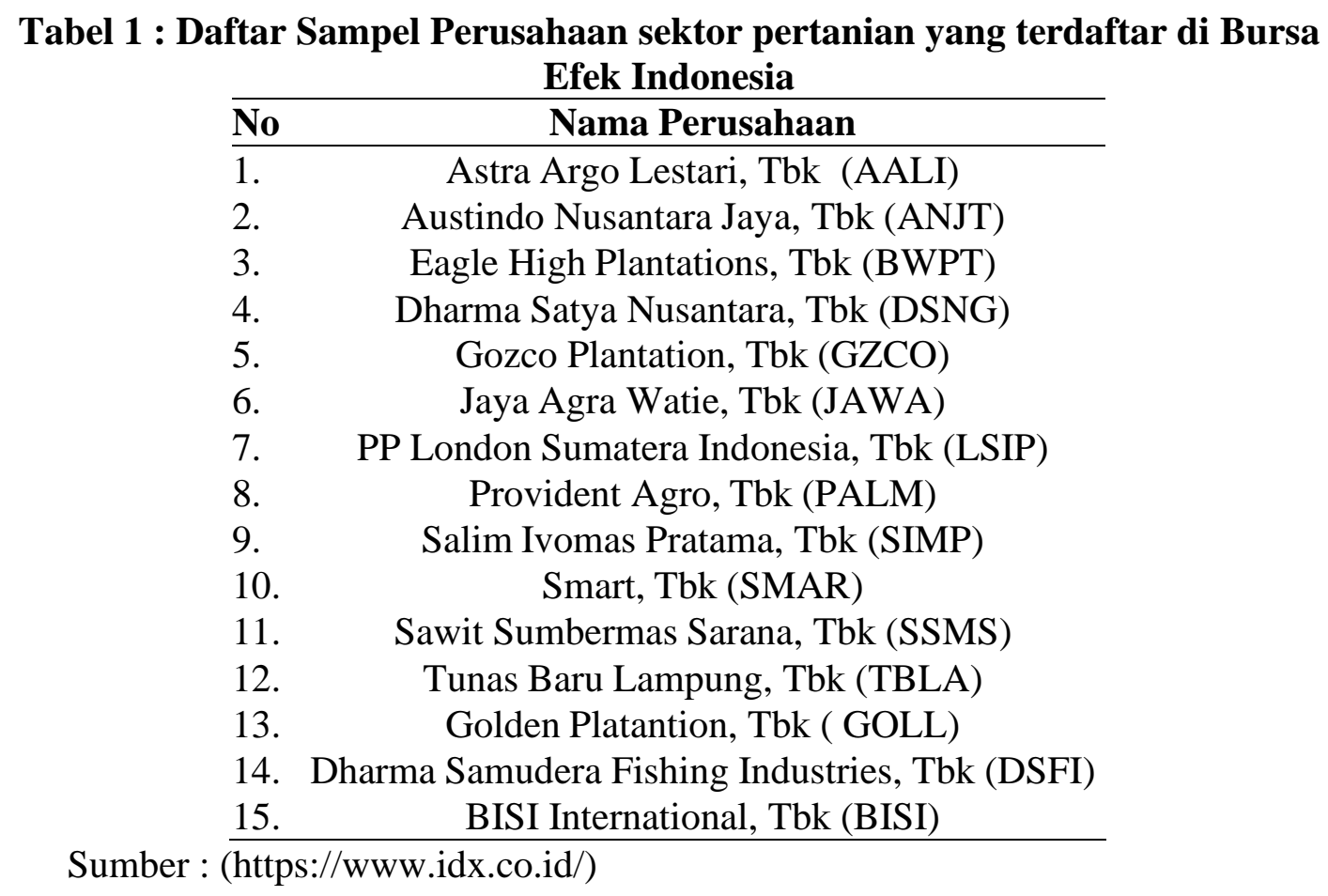

\section{Teknik Analisis Data}

Analisis regresi sederhana dapat digunakan untuk memprediksi satu variabel independen dan satu variabel dependen.Penggunaan analisis regresi sederhana untuk menunjukkan jumlah sejauh mana pengaruh perencanaan pajak terhadap nilai perusahaan. Persamaan model regresi seperti dibawah ini :

$\mathrm{Y}=\alpha+\beta \mathrm{x}$

Keterangan :

$\alpha=$ Konstanta 
$\mathrm{x}=$ Perencanaan Pajak

$\beta=$ Koefisien regresi

$\mathrm{Y}=$ Nilai Perusahaan

\section{HASIL DAN PEMBAHASAN}

\section{Perencanaan Pajak}

Indikator pertama dari perencanaan pajak adalah beban pajak dan laba sebelum pajak. Untuk periode tahun 2015-2019, rata-rata beban pajak dan laba sebelum pajak pada sektor pertanian dapat disajikan di tabel 4.1 dibawah ini.

Tabel 2 : Effective Tax Rate (Perencanaan Pajak) tahun 2015-2019

\begin{tabular}{ccccccc}
\hline \multirow{2}{*}{ NO } & \multirow{2}{*}{ NAMA PERUSAHAAN } & \multicolumn{5}{c}{ TAHUN } \\
\cline { 3 - 7 } & & $\mathbf{2 0 1 5}$ & $\mathbf{2 0 1 6}$ & $\mathbf{2 0 1 7}$ & $\mathbf{2 0 1 8}$ & $\mathbf{2 0 1 9}$ \\
\hline 1 & PT ASTRA AGRO LESTARI TBK & 0,4 & 0.04 & 0.28 & 0,31 & 0,63 \\
2 & PT AUSTINDO NUSANTARA JAYA TBK & 1,6 & 0,52 & 0,35 & 1,07 & $-1,6$ \\
3 & PT EAGLE HIGH PLANTANTIONS & 0,1 & $-0,16$ & $-0,13$ & 0,24 & 0,19 \\
4 & PT DHARMA SATYA NUSANTARA TBK & 0,29 & 0,25 & 0,29 & 0,29 & 0,36 \\
5 & PT GOZCO PLANTANTION TBK & 0,42 & 0,02 & 0,19 & 0,15 & 0,06 \\
6 & PT JAYA AGRA WATIE TBK & $-3,18$ & $-0,01$ & $-0,14$ & 0,01 & $-0,1$ \\
7 & PP LONDON SUMATERA INDONESIA TBK & 0,24 & 0,23 & 0,24 & 0,21 & 0,28 \\
8 & PT PROVIDENT AGRO TBK & 0,07 & 0,12 & 0,09 & $-0,28$ & $-0,01$ \\
9 & PT SALIM IVOMAS PRATAMA TBK & 0,46 & 0,56 & 0,41 & 1,86 & $-2,25$ \\
10 & PT SMART TBK & $-0,86$ & $-0,81$ & 0,01 & 0,01 & 0,22 \\
11 & PT SAWIT SUMBERMAS SARANA TBK & 0,24 & 0,3 & 0,27 & 0,74 & 0,92 \\
12 & PT TUNAS BARU LAMPUNG TBK & 0,23 & 0,22 & 0,23 & 0,26 & 0,26 \\
13 & PT GOLDEN PLANTANTION & 0,2 & 0,46 & $-0,49$ & 0,15 & 0,14 \\
14 & PT DHARMA SATYA NUSANTARA TBK & 0,38 & 0,25 & 0,26 & 0,24 & $-0,23$ \\
15 & PT BISI INTERNATIONAL TBK & 1 & 0,25 & 0,22 & 0,2 & $-0,24$ \\
& & $1,59 \%$ & $2,20 \%$ & $1,80 \%$ & $5,46 \%$ & $1,17 \%$ \\
\hline
\end{tabular}

Sumber : Data sekunder yang diolah, 2021

Berdasarkan tabel 2. diatas menunjukkan bahwa total Effective Tax Rate (ETR) pada tahun 2015 sebesar 1,59\% dan meningkat sebesar 2,20\% pada tahun 2016, meningkatnya ETR pada tahun 2016 dikarenakan rata- rata perusahaan mendapatkan pendapatan yang tinggi terutama pada perusahaan PT Bisi International dan PT Austindo Nusantara Jaya. Pada tahun 2017 ETR menurun sebesar 1,80\%, menurunnya ETR pada tahun 2017 dikarenakan rata-rata perusahaan mengalami penurunan dari segi pendapatan perusahaan terutama pada PT Golden Plantantion, PT Jaya Agra Watie dan PT Eagle High Plantantions. Pada tahun 2018 ETR naik sebesar 5,46\% kenaikan ETR dikarenakan pendapatan dan biaya-biaya yang dikeluarkan perusahaan-perusahaan cenderung stabil dan pada tahun 2019 ETR menurun diakibatkan karena perusahaan mengalami penurunan pendapatan terutama pada PT Salim Ivomas Pratama. Dari hasil diatas dapat disimpulkan bahwa setiap perubahan ETR tergantung dari pendapatan perusahaan dan biaya operasional yang dikeluarkan perusahaan, semakin tinggi biaya yang dikeluarkan perusahaan maka dapat mempengaruhi beban pajak perusahaan itu sendiri. 


\section{Price Earnig Ratio (PER)}

Indikator pertama dari PER adalah harga saham dan laba per lembar saham. Untuk periode tahun 2015-2019 rata rata harga saham dan laba per lembar saham pada sektor pertanian dapat disajikan di tabel 3 dibawah ini

Tabel 3 : Price Earning Ratio (PER) tahun 2015-2019

\begin{tabular}{clccccc}
\hline \multirow{2}{*}{ NO } & NAMA PERUSAHAAN & $\mathbf{2 0 1 5}$ & $\mathbf{2 0 1 6}$ & $\mathbf{2 0 1 7}$ & $\mathbf{2 0 1 8}$ & $\mathbf{2 0 1 9}$ \\
\hline 1 & PT ASTRA AGRO LESTARI TBK & 40,32 & 21,14 & 12,59 & 12 & 76 \\
2 & PT AUSTINDO NUSANTARA JAYA & & & & & \\
& TBK & $-47,37$ & 60,37 & 6,26 & 734,81 & -1 \\
3 & PT EAGLE HIGH PLANTANTIONS & $-24,2$ & $-21,56$ & $-20,71$ & $-14,59$ & -3 \\
4 & PT DHARMA SATYA & 23,58 & 253,01 & 11,21 & 11,76 & 35 \\
& $\quad$ NUSANTARATBK & $-18,56$ & $-1,24$ & $-1,91$ & $-1,38$ & -1 \\
6 & PT GOZCO PLANTANTION TBK & $-70,25$ & $-2,63$ & $-5,52$ & $-2,48$ & -1 \\
7 & PT JAYA AGRA WATIE TBK & & & & & \\
7 & PP LONDON SUMATERA & 14,45 & 32,7 & 12,69 & 18,56 & 35,78 \\
8 & INDONESIA TBK & $-54,81$ & 19,41 & 25,24 & 228,24 & $-32,21$ \\
9 & PT PROVIDENT AGRO SALIM IVOMAS PRATAMA TBK & 19,85 & 19,85 & 14,33 & 64,61 & $-13,91$ \\
10 & PT SMART TBK & $-31,24$ & 3,85 & 11,99 & 701,65 & 14,06 \\
11 & PT SAWIT SUMBERMAS SARANA & & & & & \\
& TBK & 33,11 & 44,72 & 18,15 & 24,78 & 717 \\
12 & PT TUNAS BARU LAMPUNG TBK & 13,83 & 8,47 & 6,9 & 6,45 & 7,15 \\
13 & PT GOLDEN PLANTANTION & $-20,31$ & 15,82 & $-16,32$ & $-1,73$ & -3 \\
& PT DHARMA SATYA & & & & & \\
& $\quad$ NUSANTARATBK & 8,36 & 61,34 & 17,54 & 32,53 & 16 \\
15 & PT BISI INTERNATIONAL TBK & 15,35 & 18,33 & 18,37 & 16 & 11 \\
& $\quad$ TOTAL & $97,89 \%$ & $533,58 \%$ & $110,81 \%$ & $361,59 \%$ & $856,87 \%$ \\
\hline
\end{tabular}

Sumber : Data sekunder yang diolah, 2021

Berdasarkan tabel diatas total PER pada tahun 2015 sebesar 97,98\% dan meningkat sebesar 533,58\% pada tahun 2016. Meningkatnya harga saham dikarenakan pada tahun 2016 harga penutupan saham tahun 2016 masing-masing perusahaan cenderung tinggi mengakibatkan perusahaan mengalami kenaikan PER dari tahun sebelumnya. Kenaikan PER terttinggi terjadi pada PT Dharma Satya Nusantara.Pada tahun 2017 PER mengalami penurunan diakibatkan harga saham penutupan perusahaan pada tahun tersebut cukup menurun terutama pada PT Gozco Plantantion dan PT Jaya Agra Watie.Pada tahun 2018 dan 2019 PER mengalami kenaikan diakibatkan harga saham penutupan dan laba per lembar saham perusahaan-perusahaan cenderung stabil.Dari hasil diatas dapat disimpulkan bahwa PER tergantung dari harga saham dan laba per saham perusahaan. Jikalau harga saham perusahaan semakin tinggi dan laba per saham perusahaan juga membaik maka akan diikuti oleh kenaikan PER. Makin besar atau tinggi PER suatu perusahaan maka harga saham semakin mahal terhadap pendapatan bersih per sahamnnya. Price Earning Ratio (PER) jikalau semakin besar maka akan menunjukkan prospek perusahaan yang bagus. 
Tabel 4 : Hasil Analisis Coefficients ${ }^{\text {a }}$

\begin{tabular}{ccccccc}
\hline \multirow{2}{*}{ Model } & \multicolumn{2}{c}{$\begin{array}{c}\text { Unstandardized } \\
\text { Coefficients }\end{array}$} & $\begin{array}{c}\text { Standardized } \\
\text { Coefficients }\end{array}$ & & \\
\cline { 2 - 4 } & B & Std. Error & Beta & t & Sig. \\
\hline 1 & 36,189 & 16,848 & & 2,148 & 0,035 \\
$($ Constant $)$ & ETR & 51,020 & 25,227 & 0,230 & 2,022 & 0,047 \\
\hline
\end{tabular}

a. Dependent Variable: PER

Sumber : Data sekunder yang diolah, 2021

Berdasarkan hasil uji coefficients di atas diperoleh persamaan regresi sebagai berikut :

$$
\mathrm{Y}=36,189+51,020 \mathrm{X} 1
$$

Dari persamaan regresi diatas maka dapat dijelaskan sebagai berikut :

1. Jika $=$ Konstanta sebesar 36,189 artinya apabila variabel independen yaitu perencanaan pajak dianggap konstanta (0), maka variabel dependen yaitu nilai perusahaan akan bernilai 36,189

2. Nilai koefisien regresi dari perencanaan pajak 51,020 artinya apabila variabel perencanaan pajak mengalami peningkatan sebesar satu satuan maka akan menurun nilai perusahan sebesar 51,020.

\section{Uji Koefisien Determinasi}

Uji koefisien determinasi digunakan untuk mengukur seberapa jauh kemampuan dalam menerangkan variasi variabel independent terhadap variabel dependen. Nilai koefisien determinasi yang ditunjukan dengan nilai $\mathrm{R}$ Square dari model regresi adalah 0,053 yang digunakan untuk mengetahui besarnya variabilitas variabel dependen yang dapat dijelaskan oleh variabel bebas dan dapat dilihat pada tabel dibawah ini :

Tabel 5 : Hasil Uji Koefisien Determinasi

\begin{tabular}{cccrc}
\hline Model & R & R Square & Adjusted R Square & Std. Error of the Estimate \\
\hline 1 & $0,230^{\mathrm{a}}$ & 0,053 & 0,040 & 142,84731 \\
\hline
\end{tabular}

a. Predictors: (Constant), ETR

Sumber : Data sekunder yang diolah, 2021

Berdasarkan tabel 5 model summary diperoleh nilai $\mathrm{R}$ yang menunjukkan bahwa nilai variabilitas variabel dependen yaitu nilai perusahaan yang dapat dijelaskan oleh variabel independen perencanaan pajak sebesar 0,053 sedangkan pengaruh sisanya merupakan variabel lainnya yang tidak diteliti dalam penelitian ini.

\section{Pengujian Hipotesis}

Berdasarkan hasil analisis regresi nilai signifikasi perencanaan pajak sebesar 0,047 dimana nilai tersebut lebih kecil dari taraf signifikasi penelitian yaitu $(0,047<0,05)$ selain itu dapat dilihat juga hasil perbandingan t hitung sebesar 2,022 sedangkan t tabel sebesar 1,993 dari hasil tersebut terlihat nilai $\mathrm{t}$ hitung $>\mathrm{t}$ tabel yaitu 2,022 >1,993 maka dapat disimpulkan $\mathrm{H} 0$ ditolak dan $\mathrm{H} 1$ diterima yang artinya perencanaan pajak berpengaruh signifikasi terhadap nilai perusahaan.

Berdasarkan penyajian data dari hasil penelitian yang telah dilakukan, maka peneliti dalam pembahasan ini akan membahas hasil penelitian sesuai dengan permasalahan yang 
penulis ajukan. Pembahasan ini merupakan jawaban atas permasalahan, sehingga dapat diketahui gambaran tentang ada tidaknya pengaruh antara variabel bebas yaitu perencanaan pajak dan variabel terikat yaitu nilai perusahaan

\section{Pengaruh Perencanaan Pajak Terhadap Nilai Perusahaan}

Berdasarkan hasil uji ANOVA diperoleh nilai t-tabel 1,993 lebih kecil dari t hitung 2,022 atau signifikan sebesar $0,047<0,05$. Dengan hasil tersebut perencanaan pajak memiliki pengaruh positif dan signifikan terhadap nilai perusahaan. Yang mana apabila beban pajak naik akan diikuti dengan kenaikan ETR. Dengan meningkatnya ETR maka diikuti dengan meningkatnya PER. Menurut (Lanis \& Richardson, 2012) Tarif Pajak Efektif dinilai menjadi indikator adanya perencanaan pajak. Semakin rendah nilai Tarif Pajak Efektif maka semakin tinggi tingkat perencanaan pajak.tarif pajak efektif yang rendah menunjukkan beban pajak penghasilan lebih kecil dari pendapatan sebelum pajak.

Menurut (Brigham \& Houston, 2019) Makin besar atau tinggi PER suatu perusahaan maka harga saham semakin mahal terhadap pendapatan bersih per sahamnnya.Price Earning Ratio (PER) jikalau semakin besar maka akan menunjukkan prospek perusahaan yang bagus. Berdasarkan penelitian yang dilakukan oleh (Herawati \& Ekawati, 2016) dan (Hani, 2021) bahwa perencanaan memiliki pengaruh yang signifikan terhadap nilai perusahaan.Hal ini dikarenakan setiap perencanaan pajak yang dilakukan memiliki dampak langsung terhadap nilai PER, sehingga dapat mempengaruhi nilai perusahaan.

\section{PENUTUP}

Penelitian ini dilakukan dengan tujuan menguji pengaruh perencanaan pajak terhadap nilai perusahaan pada perusahaan pertanian yang terdaftar di Bursa Efek Indonesia tahun 2015-2019. Berdasarkan hasil pengujian hipotesis dalam penelitian ini hasil temuan penelitian dapat disimpulkan bawha hasil pengujian yang dilakukan pengaruh perencanaan pajak terhadap nilai perusahaan nilai t hitung 2,022 sedangkan $t$ tabel 1,993 t hitung $>\mathrm{t}$ tabel $(2,022>1,993)$ dengan tingkat signifikasi sebesar 0,047 yang lebih kecil dari 0,05 sehingga disimpulkan bahwa variabel perencanaan pajak berpengaruh positif secara siginfikan terhadap nilai perusahaan. Hasil penelitian ini berhasil membuktikan bahwa perencanaan pajak berpengaruh positif dan signifikan terhadap nilai perusahaan pada sektor pertanian yang terdaftar di Bursa Efek Indonesia tahun 2015-2019. Dengan meningkatknya Tarif Pajak Efektif maka diikuti dengan meningkatnya nilai laba per saham yang dimana akan mempengaruhi harga saham perusahaan. Penelitan ini sejalan dengan penelitian yang dilakukan oleh (Herawati \& Ekawati, 2016) dan (Hani, 2021) yang menunjukkan perencanaan pajak berpengaruh positif dan signifikan terhadap nilai perusahaan.

Penelitian ini menggunakan metode kuantitatif dan data yang digunakan adalah data sekunder, populasi dan sampel penelitian ini adalah perencanaan pajak dan nilai perusahaan dari tahun 2015-2019.Teknik pengambilan sampel adalah teknik purposive sampling. Sumber data dalam penelitian ini diperoleh dari website yang berkaitan dengan variabel penelitian.

Adapun saran-saran dapat penulis berikan sehubungan dengan keterbatasan penelitian ini sebagai berikut : 
Dari hasil penelitian diharapkan memberikan informasi yang bermanfaat dalam pengambilan keputusan yang tepat dalam menentukan alternatif pilihan investasinya. Apabila investor ingin melakukan investasi agar sebelum berinvestasi sebaiknya investor memilih perusahaan yang punya informasi tentang laporan keuangan yang lebih jelas dan melihat laba perusahaan tersebut.

b. Bagi Perusahaan Sektor Pertanian

Diharapkan agar lebih meningkatkan kinerja perusahaan dan memperhatikan variabel perencanaan pajak yang dianggap penting dalam perusahaan yang dapat mempengaruhi harga saham dan meningkatkan nilai perusahaan

c. Bagi penelitian selanjutnya

Diharapkan dapat meningkatkan penelitian ini dengan menggunakan subjek penelitian yang lebih luas, dan peneliti juga diharapkan melakukan pengujian terhadap variabel lain yang mempengaruhi nilai perusahaan.

\section{DAFTAR PUSTAKA}

Brigham, E. F., \& Houston, J. F. (2019). Dasar-Dasar Manajemen Keuangan: Essensial of Financial Management Buku 1.

Hani, S. (2021). Pengaruh Perencanaan Pajak Terhadap Nilai Perusahaan Pada Perusahaan Manufaktur Yang Terdaftar Di Bursa Efek Indonesia.

Herawati, H., \& Ekawati, D. (2016). Pengaruh perencanaan pajak terhadap nilai perusahaan. Jurnal riset akuntansi dan keuangan, 4(1), 873-884.

Indriati, D. (2017). Analisis Penerapan Perencanaan Pajak Penghasilan Pasal 21 Pada PT Jaya Mestika Indonesia. Jurnal Ilmu dan Riset Akuntansi (JIRA), 6(8).

Laksitasari, V. (2018). Pengaruh Biaya Penelitian dan Pengembangan Terhadap Tarif Pajak Efektif dengan Corporate Governance sebagai Variabel Moderasi. STIE YKPN,

Lanis, R., \& Richardson, G. (2012). Corporate social responsibility and tax aggressiveness: An empirical analysis. Journal of Accounting and Public policy, 31(1), 86-108.

Mardiasmo. (2018). Perpajakan. Yogyakarta: Penerbit ANDI.

PSAK. 46 (Revisi 2010),". Akuntansi Pajak Penghasilan.

Putri, V. R. (2018). Analisis Faktor Yang Mempengaruhi Effective Tax Rate. Jurnal Akuntansi Keuangan dan Bisnis, 11(1), 42-51.

Sari, N. M. Y. D. P., \& Chabachib, M. (2013). Analisis Pengaruh Leverage, Efektivitas Aset dan Sales Terhadap Profitabilitas serta Dampaknya Terhadap Nilai Perusahaan (Studi Pada Perusahaan Di Sektor Industri Barang Konsumsi Yang Terdaftar Di Bursa Efek Indonesia Periode Tahun 2007-2011). Fakultas Ekonomika dan Bisnis,

Suandy, E. (2016). Hukum Pajak (Edisi tujuh ed.). Jakarta: Penerbit Salemba Empat.

Sugiyono, S. (2019). Metode Penelitian Kuantitatif Kualitatif dan R\&D. Alfabeta. In.

Sutama, D., \& Lisa, E. (2018). Pengaruh leverage dan profitabilitas terhadap nilai perusahaan. JSMA (Jurnal Sains Manajemen Dan Akuntansi), 10(1), 21-39.

Yuliem, M. L. (2018). Pengaruh Perencanaan Pajak (Tax Planning) Terhadap Nilai Perusahaan (Firm Value) Pada Perusahaan Sektor Non Keuangan Yang Terdaftar Di BEI Periode 2013-2015. Calyptra, 7(1), 520-540. 